\title{
Level of Knowledge and Behavior of Nurses in Pain Management in Children When an Invasive Action Is Procedures
}

\author{
Wesiana Heris Santy ${ }^{1,2 *(D)}$, I. Dewa Gede Ugrasena ${ }^{3}$, Yuni Sufyanti Arief ${ }^{4}$, Fauziyatun Nisa $^{5} \mathbb{D}$, Siti Nur Hasina $^{2}$ (D) \\ ${ }^{1}$ Doctoral Program, Faculty of Nursing, Universitas Airlangga, Surabaya, East Java, Indonesia; ${ }^{2}$ Department of Nursing, Faculty \\ of Nursing and Midwifery, Universitas Nahdlatul Ulama Surabaya, Surabaya, East Java, Indonesia; ${ }^{3}$ Department of Pediatric, \\ Faculty of Medicine, Universitas Airlangga, Surabaya, East Java, Indonesia; ${ }^{4}$ Department of Pediatric Nursing, Faculty of \\ Nursing, Universitas Airlangga, Surabaya, East Java, Indonesia; ${ }^{5}$ Department of Midwifery, Faculty of Nursing and Midwifery, \\ Universitas Nahdlatul Ulama Surabaya, Surabaya, East Java, Indonesia
}

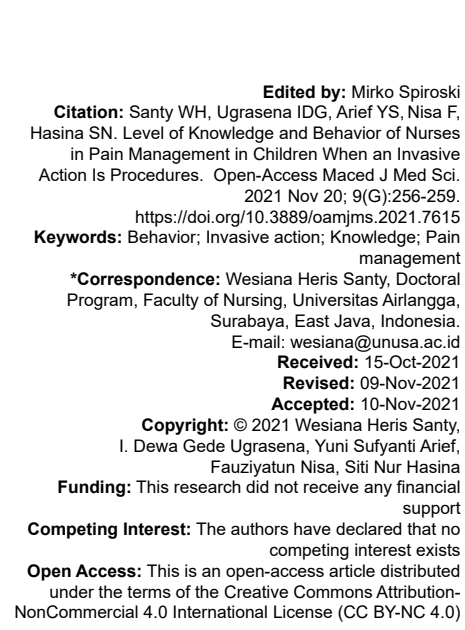

\section{Introduction}

Knowledge is a very important domain in shaping one's actions (Notoatmodjo, 2012) [1]. Likewise with the knowledge and attitudes of nurses about pain management in children, it is very useful for the accuracy of carrying out invasive actions in children [2]. Lack of knowledge and inappropriate attitudes towards pain management has been recognized as a major obstacle in the implementation of pain management by health workers [3]. The implementation of pain management cannot be separated from the attitude, experience, and other influencing factors. Most nurses carry out pain management when performing invasive procedures on children who are not good.

Findings from the PAMPER study on pain management practices, nurses revealed that only $26.7 \%$ (40 of 150) children presenting to the ED with moderate to severe pain received analgesics and only
$16.7 \%$ (25 of 150 ) were given the intervention. nonpharmacological. While the results from Trihastutik et al. in 2019 showed that nurses' knowledge in pain management was $9.1 \%$ less, $67.3 \%$ moderate, $23.6 \%$ good, and the behavior or attitude of nurses in pain management was $29.1 \%$ positive, $70.9 \%$ negative attitude [4]. Based on the results of observations during the practicum at Rumah Sakit Islam A. Yani, the phenomena that occur in the children's room are still very less effective. The busyness of nurses is the reason that nurses forget to apply good pain management to children when performing invasive procedures.

Effective pain management has not been achieved due to various obstacles including lack of knowledge, personal principles, feelings influenced by others, ability to assess pain, decision making, and use of journal-based information for pain management and poor pain judgment [5].

In pain management when invasive measures are performed on children, nurses can 
use two actions, namely pharmacological measures and non-pharmacological measures. Nurses using their knowledge can overcome pain problems by performing invasive measures on children both independently and collaboratively. Efforts that can be made are nurses can add experience by attending seminars, reading journals, or articles about pain and appropriate pain management in addition, to increase nurses' knowledge about pain management during invasive procedures. namely by participating in trainings [5].

\section{Methods}

The research approach used was crosssectional where the independent variable (level of knowledge), and the dependent variable (nurse behavior when performing invasive procedures on children) were assessed at the same time. The population of this study were nurses who performed invasive procedures in the nursery at RSI A. Yani Surabaya. The population in this study was 30 nurses. In this study, the sampling technique with the total sampling technique is a sampling technique where the number of samples is the same as the population of 30 nurses. This research was conducted at Rumah Sakit Islam A. Yani Surabaya in January 2021.

The questionnaire in this study at the level of knowledge emphasized on nurses' understanding of pain, giving techniques in pain management and ways to overcome problems in pain management. as for behavioral questionnaires are categorized as positive behavior if the average value is $>50$ and the average negative behavior is $<50$ in which there are 10 questions.

The analysis used is the Fisher Exact Test using the SPSS version 12.0 for windows program with a significant level of $=0.05$. Research that uses humans as subjects should not conflict with ethics. The research objective must be ethical in the sense that the respondent's rights must be protected, so that this research has been approved by the Health Research Ethics Committee, Universitas Nahdlatul Ulama Surabaya with Number 234/EC/KEPK/ UNUSA/2020.

\section{Results}

The research results obtained by the researchers are as follows:

Based on Table 1, it shows that of the 30 nurses, the gender of the nurses was mostly $(86.7 \%)$
26 respondents were women. the age of nurses mostly $(53.3 \%)$ were 16 respondents, namely late adults. the most recent education of nurses (63.3) 19 respondents educated in nursing profession.

Table 1: Frequency distribution of respondents by gender, age, and education of nurses

\begin{tabular}{lll}
\hline Characteristics of respondents & Frequency & Percentage \\
\hline Gender & & \\
$\quad$ Man & 4 & 13.3 \\
$\quad$ Woman & 26 & 86.7 \\
Age & 14 & 46.7 \\
$\quad$ Early Adults (26-35 years) & 16 & 53.3 \\
$\quad$ Late Adults (36-50 years) & & \\
Education & 11 & 36.7 \\
$\quad$ Diploma 3 Nursing & 19 & 63.3 \\
$\quad$ Nurse Profession & & \\
\hline
\end{tabular}

Based on Table 2, it shows that the nurses' knowledge of pain management in children when invasive procedures were carried out (given a questionnaire) was mostly $(66.7 \%)$ of 20 respondents, which were enough knowledgeable.

Table 2: Frequency distribution of respondents based on nurses' knowledge of pain management in children during invasive procedures

\begin{tabular}{lll}
\hline Knowledge & Frequency & Percentage \\
\hline Well & 4 & 13.3 \\
Enough & 23 & 76.7 \\
Not enough & 3 & 10.0 \\
\hline
\end{tabular}

Based on Table 3, it shows that the nurse's behavior toward pain management in children when invasive measures are carried out (observation sheets) (70.0\%) 21 respondents are positive behavior.

Table 3: Frequency distribution of respondents based on the behavior of nurses on pain management in children during invasive procedures

\begin{tabular}{lll}
\hline Behavior & Frequency & Percentage \\
\hline Positive & 21 & 70 \\
Negative & 9 & 30 \\
\hline
\end{tabular}

Based on Table 4, it shows that there are 23 respondents who have sufficient knowledge with 18 respondents having positive behavior and 5 respondents being negative. While 4 respondents who have good knowledge with positive behavior 3 respondents and 1 respondent behaves negatively. respondents who have less knowledge there are 3 respondents with negative behavior.

Table 4: Cross tabulation of knowledge and behavior of nurses on pain management in children during invasive procedures

\begin{tabular}{llll}
\hline Knowledge & \multicolumn{2}{c}{ Perilaku (\%) } & Total (\%) \\
\cline { 2 - 3 } & Positive & Negative & \\
\hline Well & $3(75)$ & $1(25)$ & $4(100)$ \\
Enough & $18(78.3)$ & $5(21.7)$ & $23(100)$ \\
Not enough & $0(0)$ & $3(100)$ & $3(100)$ \\
Total & $21(70)$ & $9(30)$ & $30(100)$ \\
\hline
\end{tabular}

The results of the chi-square test obtained 4 cells $(66.7 \%)$ EF value $<5$ means that it does not meet the requirements of the chi-square test, for that using the fisher exact test and the $p=0.033(p<0.05)$ then there is a knowledge relationship with the behavior of nurses on pain management in children during invasive procedures at RSI A. Yani Surabaya. 


\section{Discussion}

\section{Nurses knowledge level in pain management in children during invasive procedures}

Based on Table 2, the nurse's level of knowledge about pain management in children when invasive procedures were carried out was the most $(76.7 \%) 23$ respondents were at the level of sufficient knowledge, while having a good knowledge level of 4 people $(13.3 \%)$ and having a knowledge level of less than 3 people $(10.0 \%)$. The level of sufficient knowledge in this study shows that nurses have a basic knowledge of pain management which is considered sufficient, but it would be even better if the knowledge of nurses was in a good category so that nurses had a strong knowledge base in pain management in children when invasive measures were carried out so that when performed invasive measures the child does not cry or struggle with fear.

Good knowledge is supported by $4(13.3 \%)$ nurses providing treatment actions, one technique that can be done by child nurses in reducing fear and pain in children is Invite children to play and tell stories related to the action or procedure to be carried out, the handling process pain often cannot be eliminated quickly, but can be reduced by various distraction/touch techniques, the physiological response shown if the child (baby) experiences pain is crying and skin to skin contact is one way to reduce pain in infants, one of the ways to reduce pain in infants. the way is by way of kangaroo mother care. This sufficient knowledge is supported by $23(76.6 \%)$ nurses. Physiological response is shown if the child (infant) experiences pain, namely crying and nurses understand the meaning of pain $20(66.6 \%)$. While knowledge is not supported by $3(10 \%)$ nurses understand the meaning of pain.

The results of this study are different from the research conducted by Maghami et al. (2016) which showed that nurses' knowledge related to pain perception showed that the results of nurses' knowledge ranged between moderate and high [6]. Another study conducted by Mathew et al. (2011) on nurses' knowledge, attitudes and practices toward pain in developing countries showed that there is a gap between knowledge and practice of pain in nurses that requires improvement through training [7].

\section{The level of behavior of nurses in pain management in children during invasive procedures}

Based on Table 3, it shows that of the 30 nurses have a positive attitude category as many as 21 respondents $(70.0 \%)$ and 9 respondents $(30.0 \%)$ have a negative category. In this study, there were more positive attitudes than nurses who had negative attitudes. This can be due to nursing education factors, both Diploma 3 Nursing and Bechelor of Nursing. It is not only knowledge that affects the behavior of nurses in children when invasive procedures are carried out, but also it could be due to long working hours as a nurse and there are procedures for pain management from A. Ani Hospital Surabaya that nurses must do so that many nurses behave positively.

The positive behavior of nurses in pain management in children when invasive measures are carried out is supported by preparing pain management tools, namely 6 nurses $(20 \%)$ using toys: Colorful pictures and pictures of tools or pain scales, 7 nurses $(23.3 \%)$ providing mobile media to display animations and songs, and 1 nurse (3.3\%) provided composited media. While the negative behavior of nurses in pain management in children when invasive actions are carried out is supported by cellphone media to display cartoon animations, namely 1 nurse (3.3\%).

\section{The relationship between the level of knowledge and the behavior of nurses in pain management in children during invasive procedures}

Based on Table 4, it shows that there are 23 respondents who have sufficient knowledge entirely $100 \%$ nurses with positive and negative behavior. While 4 respondents who have good knowledge are all $100 \%$ nurses with positive and negative behavior, and 3 respondents who have less knowledge are all $100 \%$ nurses with negative behavior. Other studies show that in general nurses and doctors have sufficient knowledge about pain management in children, but there is still a gap between knowledge and practice of pain management [8].

Based on the results of statistical analysis of the results of the Chi-square test, it was found that 4 cells $(66.7 \%)$ EF value $<5$ means that it does not meet the requirements of the chi-square test, for that we use the fisher exact test and the value of $p=0.033(p<0.05)$ then $\mathrm{Ho}$ is rejected and $\mathrm{H} 1$ is accepted, meaning that there is a relationship between knowledge and behavior of nurses on pain management in children when invasive procedures are performed at RSI A. Yani Surabaya.

This opinion is in line with Zubaidah's research (2018), which was conducted by 44 respondents to determine the knowledge and behavior of nurses in pain management during invasive procedures. From the results of the study, it was found that there was a significant relationship between the knowledge and behavior of nurses in pain management during invasive procedures [9]. Interventions in pain management are very important for children who have pain during invasive procedures, this is as stated in the research of Herlina et al. (2011) [10] showing that there is a difference in pain response scores between those 
given pain management and those who are not given pain management. during invasive procedures.

\section{Conclusion}

The level of knowledge of nurses about pain management in children during invasive procedures obtained a enough level of knowledge. The nurse's behavior level toward pain management in children during invasive procedures is positive. The results of the analysis using statistical tests showed that there was a relationship between the knowledge and behavior of nurses about pain management in children during invasive procedures.

\section{References}

1. Notoatmodjo. Pendidikan Dan Perilaku Kesehatan. Jakarta: Rineka Cipta; 2003.

2. Hidayati NI. Studi Deskriptif Pengetahuan Dan Sikap Perawat Tentang Manajemen Nyeri Pada Neonatus Di Ruang Perinatologi Dan Picu/Nicu Rsud Tugurejo Dan Rsud K.R.M.T. Wongsonegoro Semarang. Semarang: Universitas
Muhammadiyah Semarang; 2018.

3. Putri ED. Hubungan Tingkat Pengetahuan dan Sikap dengan Penerapan Manajemen Nyeri pada Pasien Kanker oleh Perawat di Rumah Sakit Kanker Dharmais. Depok: Universitas Indonesia; 2013.

4. Thrihastutik DK. Perilaku Perawat Dalam Manajemen Nyeri Non Farmakologi Pada Neonatus Pendekatan Theory of Planned Behavior (TPB). Surabaya: Universitas Airlangga; 2019.

5. Dewi, M dan Ropyanto B. Hubungan Sikap Dan Pengalaman Pelaksanaan Manajemen Nyeri Pada Perawat Terhadap Pelaksanaan Manajemen Nyeri Pasien Pasca Operasi. Jurnal IImu Keperawatan Medial Bedah. Semarang: Universitas Diponegoro; 2011.

6. Maghami M, Aghababaeian H, Majin SA, Moosavi A, Tahery N. Knowledge, attitude and performance of the nurses working in neonatal wards about treatment of pain in neonates. J Chem Pharm Sci. 2016;9:2796-801.

7. Mathew PJ, Mathew JL, Singhi S. Knowledge, attitude and practice of pediatric critical care nurses towards pain: Survey in a developing country setting. J Postgrad Med. 2011;57(3):196-200. http://doi.org/10.4103/0022-3859.85203 PMid:21941056

8. Akuma AO, Jordan S. Pain management in neonates: A survey of nurses and doctors. J Adv Nurs. 2011;68(6):1288-301. http://doi.org/10.1111/j.1365-2648.2011.05837.x PMid:21988718

9. Zubaidah Z, Nafiyati E. Hubungan Pengetahuan Dan Sikap Perawat Dengan Praktik Manajemen Nyeri Pada Neonatus. Universitas Diponegoro: FKUD; 2018.

10. Bindler RC, Ball JW, Cowen KJ. Principles of Pediatric Nursing: Caring for Children. $5^{\text {th }}$ ed. New Jersey: Pearson Education Inc.; 2011. 